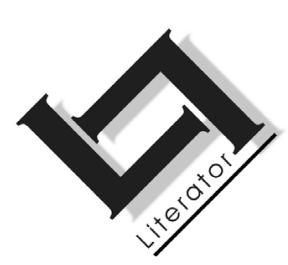

\title{
The trace of Jewish suffering in Johannes Bobrowski's poetry
}

\author{
F. Wittenberg 1 \& $\mathrm{H}$. Wittenberg \\ Department of English \\ University of the Western Cape \\ BELVILLE
}

E-mail: hwittenberg@uwc.ac.za

People, you talk oblivion -

... remember the trail of blood.

\begin{abstract}
The trace of Jewish suffering in Johannes Bobrowski's poetry

Johannes Bobrowski (1917-1965) is a significant German modernist poet and novelist whose work directly engages the problematic question of German "Schuld" (guilt) in respect of the Holocaust. Although Bobrowski's poetry not only deals with the German-Jewish question, but with universal themes of history, memory and trauma, he is largely unknown in the Anglophone world, partly because of his isolation in communist East Germany at the time. This article seeks to trace Bobrowski's nuanced and complex engagement with German history and his own personal implication in the genocide through a detailed analysis of his most significant "Jewish" poems. A key idea for Bobrowski was the need for memory and direct engagement with the traumatic past, as this offered the only hope for redemption. The article presents a number of original English translations of these symbolist and hermetic poems, and thereby makes Bobrowski's writing available to a wider range of readers.
\end{abstract}

1 Due to illness, the principal author, Friedrich Wittenberg, could not finalise this article. Revisions and editing were undertaken by his son, Hermann Wittenberg. 


\section{Opsomming}

\section{Spore van Joodse lyding in Johannes Bobrowski se gedigte}

Johannes Bobrowski (1917-1965) is 'n belangrike modernistiese Duitse digter en romanskrywer wie se werk direk handel oor die problematiek van Duitse "Schuld" (skuld) oor die Jodevervolging. Hoewel Bobrowski se poësie nie beperk is tot die Duits-Joodse vraagstuk nie, maar oor universele temas rondom geskiedenis, herinnering en trauma handel, is hy grootliks onbekend in die Engelstalige wêreld, deels weens sy naoorlogse isolasie in Oos-Duitsland. Hierdie artikel ondersoek Bobrowski se genuanseerde en komplekse omgang met die Duitse geskiedenis en sy persoonlike medepligtigheid aan die menseslagting deur middel van 'n indringende analise van sy belangrikste "Joodse" gedigte. 'n Kerngedagte by Bobrowski was die noodsaaklikheid van herinnering en direkte betrokkenheid by die traumatiese verlede, omdat dit die enigste hoop op bevryding daarvan bied. 'n Aantal oorspronklike Engelse vertalings van hierdie simbolistiese en hermetiese gedigte word ingesluit om die skrywer se werk vir 'n wyer leserspubliek toeganklik te maak.

\section{Introduction: "Two sentences for a book on Germany"}

In the winter of 1964, in the cold month of January, the East German poet Johannes Bobrowski (1917-1965) wrote a short prose piece and a poem on the subject of the Holocaust. The prose text he called Zwei Sätze für ein Deutschlandbuch ("Two sentences for a book on Germany"), and the poem was titled Wiedererweckung ("Resuscitation"). This article will look at the Jewish theme in these two texts and other selected lyric writings in order to gain an understanding of Bobrowski's complex response to the Holocaust, and the larger question of guilt, atonement and redemption in German history.

Although Bobrowski's often hermetic and symbolist poems form the main subject of this article, his prose passage is such an important literary response to the Holocaust that by way of introduction it is analysed shortly. The short prose passage reads as follows:

The first two sentences for a book on Germany 2

2 The German text according to Bobrowski (1987, 4:89 ff.). The English translation - FW. 
When the first news of the mass murders of Jews reached the town and everybody was of the opinion that this was exaggerated, since it could never have been as bad as that, and yet everybody knew quite well that all of this was real, that none of those immense figures, none of those gruesome methods and refined techniques which one had heard about were exaggerated, that all of this had really taken place, since it could on no account have been otherwise, and that it was therefore no longer possible to discuss whether there might not have been milder, more humane ways, perhaps no longer banishment, now during the war, but rather guaranteed reserves with selfrule and so forth, when the time had come for utter silence, when one had already withdrawn into silence, away from who knows who and who knows what, feeling no longer a resentment rising up against anything, taking part only in superficial small talk, alternating between a casual stereotyped joke and an emotional-solemn feeling of being involved in an existential struggle of mythical proportions, against one's own free will, this granted, when this stage had been reached by all those who were running around free in Germany and continuing with their free life, under the more difficult circumstances of war, this granted, when they had managed to come thus far - which does not say very much, because so far they had always managed to cope seeing that they had things pretty well under control by now, when thus everything was as it had always been, when this was the case, bells were ringing - for nothing out of the ordinary: for the wedding of a brain damaged man, who on account of his military decorations as chief lieutenant of the pioneer troops could not be denied this wish, having been declared fit for garrison duty but provisionally placed on leave for the next few years, and his bride, the nurse Erika, who with her own hands, had cut him loose when he tried to hang himself from a window frame in the Sanatorium, and whom he on the eve of his wedding day then strangled, apparently in a bout of mental disturbance, which also does not say much about his condition, because being mentally disturbed had been his official status in any case, that is for the past two years, after his injury.

This one then for the past two years, the other one since when?

The complex syntactic structure of the text, especially the first long sentence, creates formidable translations challenges. Werner Kraft, a German Jewish writer living in Jerusalem, called this passage "extraordinary" (Tgahrt, 1993:662). It was only published posthumously and has until now received scant attention from German critics. Zwei Sätze für ein Deutschlandbuch was written for a proposed collection 
of short German prose, Deutsche Miniaturen, in January 1964. Bobrowski gave a public reading of the text to a packed audience in Berlin on 13 May 1965, a few months before his death, under the auspices of the socialist Club der Kulturschaffenden Johannes R. Becher (cf. Gajek \& Haufe, 1977:41, 47).

It demanded great courage of Bobrowski in 1965 to state that these two sentences on the mass murders of Jews and the psychopathic deed of a German officer were necessary as the "first two sentences for a book on Germany". At that time the East German ideologues in the German Democratic Republic (GDR) held that the socialist East German state could not be held accountable for crimes committed by the Germans in Nazi Germany. Furthermore, as Leah Ireland has pointed out, East Germany at that time was anti-Israel and antiZionist in its stance. The nationalist policies of the Jewish state and its demand for ethnic self-determination conflicted with Marxist internationalism (Ireland, 1980:416 ff.). Bobrowski's stance on history, culpability and memory thus sat uncomfortable with official thinking in the GDR.

Bobrowski's text is not a conventional short story but a sketch that attempts to describe the Geistesverfassung or state of mind of the German people at the end of the war after news of the mass murders finally got around. He suggests that Germans, faced with the post-war revelations about the camp atrocities attempted to dismiss them as exaggerations even though everyone fully well knew that was the truth of the genocide. Bobrowski's text shows how Germans failed to come to terms with the crimes against the Jews. Their response, according to the text, is not silence and remorse but rather rationalisation and intellectual small talk, joking, and a "solemnemotional feeling that one was involved in an existential struggle of mythical proportions, against one's own will". Intellectualising leads to finding excuses and the onus for the crimes is placed on nameless fate. Thus everything stays as it has always been. Germans, Bobrowski suggests, have learned to cope effectively with this traumatic event.

Bobrowski's text also focuses on the mental state of the brain damaged German officer, and the way in which his act of spectacular murderous madness masks a longer German history of collective irrational violence towards Jews. The officer's psychotic behaviour is characterised by an unrepressed urge to kill, but yet his behaviour is only deemed certifiably mad once the violence is directed against himself (he initially tries to commit suicide) and his bride, the nurse Erika. Bobrowski's text suggests that the monstrous 
crimes perpetrated by the German people against the Jews during the Nazi era were by implication regarded as perfectly sane and normal. The officer's murderous actions are thus not an irrational, unprecedented crazy act, but merely one of a long series of violent acts associated with the violent history of the Holocaust.

The first long sentence "for a book on Germany" is a syntactic monstrosity. Through its complex grammatical structure with its many subordinate clauses and interpolations, it mirrors not only the "madness" of the officer and thereby the mental state of the German people, but also the gruelling attempt by the narrator to come to terms with this traumatic experience in his people's history. The narrator explains that the injury which caused the mental instability of the officer and triggered his psychopathic tendency occurred two years earlier. In his second very short sentence he poses the question since when "the other one" has been going on. By this "other one" the narrator can only mean the "madness" of the German people, the collective mental derangement leading to the genocidal crime of the Holocaust. Bobrowski's text thus invites German readers to look for the roots of this "madness of Anti-Semitism" and examine its destructive consequences.

Bobrowski's poems on the fate of the Jews were written with this purpose in mind. They were published at a time when the discussion of the Holocaust and German culpability was still very restricted. Bobrowski's ideas could be summarised under the following four headings:

- Bobrowski wants his fellow countrymen to remember what Germans did to the Jews.

- He wants to establish the reality of Jewish suffering so that his countrymen could come to terms with it.

- He wants to establish the reality of German guilt, including his own culpability.

- Finally, he wants to find words or signs of consolation and hope for the Jews and the Germans which would make reconciliation possible.

These four aspects of Bobrowski's "Jewish" poems will be discussed more fully in this article. The fact that his modernist poems are written in an elusive, almost hermetic style, poses a great challenge to the reader's ability to comprehend their meaning. 


\title{
2. The trail of blood: remembrance
}

An old Jewish proverb states: "Wanting to forget lengthens the exile; to remember is the secret of deliverance." Bobrowski's poem "Holunderblüte" (Elder blossom) is a poem against forgetfulness. It pleads with Germans to remember "the trail of blood". The first stanza evokes the memory of a pogrom as reported by the Russian writer Isaak Babel who himself was a persecuted Jew and died in the Stalinist purges in 1941. Babel was a child when the pogrom in Odessa took place in 1905.

The first stanza reads as follows:

\author{
Es kommt \\ Babel, Isaak. \\ Er sagt: Bei dem Pogrom, \\ als ich Kind war, \\ meiner Taube \\ riss man den Kopf ab. \\ Here comes \\ Babel, Isaak. \\ He says: In the pogrom, \\ I was a child, \\ they tore off the head. \\ from my pigeon.
}

The multiple acts of barbarism committed during this pogrom are compressed, synechdocally, into the killing of the child's pigeon. Babel wrote about this experience in his short story "The story of my dove-cote". 3 From Babel's story we know, however, that the tenyear-old boy did not only lose his pigeon but his grandfather Schojil as well. He was murdered during the pogrom by Russian peasants. Babel writes as follows: "Kusma, the housekeeper, sat in the shed next to the corpse of Schojil and was dressing the dead man ... Do you see what those people have done to our Grandfather?"

3 Quoted according to the catalogue of the 1993 Bobrowski Exhibition at the Schillermuseum at Marbach, "Johannes Bobrowski oder Landschaft mit Leuten" (Tgahrt, 1993:333 ff.) which traces the sources (Babel and Raabe) used by Bobrowski for this poem. The translation of the poem "Holunderblüte" is by Dagmar Barnouw (Barnouw, 1973:26) 
The second stanza evokes the memory of the trail or track of blood on the white-scrubbed steps:

Häuser in hölzerner Straße, mit Zäunen, darüber Holunder.

Weiß gescheuert die Schwelle, die kleine Treppe hinab Damals, weißt du, die Blutspur.

Houses in a wooden street, with fences, over them elder. White-scrubbed the threshold, down the small steps that time, remember

the trail of blood. 4

The "trail of blood" reminds the reader not only of the 1905 pogrom but also, proleptically, of the subsequent genocide. They may not pass into oblivion, they must be remembered.

Leute, ihr redet: Vergessen -

Es kommen die jungen Menschen,

ihr Lachen wie

Büsche Holunders.

Leute, es möcht der Holunder

sterben

an eurer Vergeßlichkeit.

People, you talk oblivion -

Here come the young people,

their laughter like

bushes of elder.

People, the elder might

die

of your forgetfulness.

(Bobrowski, 1987, 1:94.)

For this act of grief and remembrance the poet finds a powerful image: the white blossom of the elder. It has been pointed out that the image of the elder blossom is a cento, an allusion to the short story by Wilhelm Raabe (published 1863) with the title "Elder blossom" (Deskau, 1975:29 ff.). In this story the elder flowering in pro-

4 Barnouw translates Blutspur as "track of blood". I have preferred the word trail, and have used this choice of translation consistently in this article. 
fusion in the old Jewish cemetery of Prague, called the "Beth-chaim" (the house of the living) takes on the significance of a blossom of death and judgement. Raabe's narrator, remembering his short love affair with the Jewish girl, Jemima Löw, from the Jewish part of the town, feels guilty that he took leave of the girl with the weak heart not heeding her words that she would soon die. Her last words to him were: "Gedenke der Holunderblüte!" ("Remember the elder blossom!") (Raabe, 1963:82).

When Bobrowski evokes the memory of the elder blossom he conveys the message that the killing of the Jews should be remembered. The poem's message to his young countrymen is thus as follows: if you deny your culpability and your guilt the elder will die and will not blossom. The evils of the past should never be repeated. Only remembrance brings forth blossoms which can bring deliverance.

In one of his interviews Bobrowski revealed that many young people wrote to him about the

... complex question of Anti-Semitism ... grappling with the 'guilt of the fathers' as they call it. ... I have to admonish the young people not to be too rigorous, since the guilt of the father generation is still our guilt, and one cannot, especially as a German, do away with one's national history. One must accept it as it is and one must try to make amends ... (Bobrowski,1987, 4:482; translation - FW).

In a poem, "An ...", dedicated to his friend Peter Jokostra whose Jewish girlfriend, Wronka, was gassed in Treblinka, Bobrowski wrote of this "active" remembrance. The poem, unpublished during his life time, is one of his most explicit and unambiguous appeals for memory. The last verses read as follows:

Und du sagst: Die Spur ist verwachsen, die Rede tönt nicht mehr um den Abend, gemordet ist Wronka.

Deutest auf diesen, und den, Gründe zählst du, du sagst:

So ist es gewesen. Sag, von dir muß ichs hören:

Es wird nie mehr so sein. 
And you say: the trail

is grown over, her voice

no longer sounding

at eventide,

Wronka has been murdered.

You point at this one and that one

You give reasons. You say:

That is what had happened. -

Say it,

from you I must hear it:

Never again shall this be.

(Bobrowski, 1987, 2:313.) 5

\section{The trail of blood: the reality of Jewish suffering}

In Bobrowski's poems on the Jewish theme remembrance is intimately bound up with the visible signs of Jewish suffering. The "trail of blood" has left its stains in nature and in the landscape as is shown by the poem to the Jewish poetess Gertrud Kolmar.

\section{Gertrud Kolmar}

Buche, blutig im Laub,

in rauchender Tiefe, bitter

im Schatten, droben das Tor

aus Elstergeschrei.

Dort ist eine gegangen,

Mädchen, mit glattem Haar, die Ebene unter den Lidern lugte herauf, in den Mooren vertropfte der Schritt.

Ungestorben aber

die finstere Zeit, umher geht meine Sprache und ist rostig von Blut.

Wenn ich deiner gedächte:

Vor die Buche trat ich, ich hab befohlen der Elster:

$5 \quad$ With the exception of "Elderblossom" the translations of all the poems quoted are F. Wittenberg's. They are taken from vol. 1 and 2 of Bobrowski's Collected works (Bobrowski, 1987, 1-4). 
Schweig, es kommen, die hier waren - wenn ich gedächte:

Wir werden nicht sterben, wir warden

mit Türmen gegürtet sein?

\section{Gertrud Kolmar}

Beech tree, bloody in foliage, in smoky depths, bitter in shadows, up there the gate of jackdaws' squawking.

There someone's been walking, maiden, with smooth hair, the plain under the eyelids leered upwards, in the moorlands the footsteps dripped away.

Undying however the dark time of gloom, my speech goes probing, and is rusty with blood.

If in thinking of you l'd remember:

I confronted the beech tree, I commanded the jackdaw:

Be still, they are coming, those who were here - if I should remember: We shall not perish, we shall be harnessed with turrets?

(Bobrowski, 1987, 1:116.)

In the first stanza, the foliage of the beech tree is said to be "bloody" and the dissonant squawking of the jackdaws taken together with the "smoky depths" conjure up vivid images of doom and death. The "trail of blood" has left indelible stains in the landscape. The landscape itself, in the form of the open plain is antagonistic ("leers upward") and offers no shelter. The death of the "maiden" in the "moorlands" of anonymity and desolation as depicted in the second stanza alludes to Gertrud Kolmar's death in a concentration camp in 1942. In the third stanza the poet suggests that even his own speech, his poetic language, is tarnished by her death: it is "rusty" with blood. It is the same language as the language of those who were responsible for the Holocaust. All the more urgent therefore the need to overcome the "finstere Zeit", the time of darkness, with active acts of remembrance, as the fourth stanza points out. The poet wants to 
harness the power of living speech to overcome the ominous signs of death in nature (beech tree, jackdaws) so that death is not the ultimate victor. Bobrowski uses a quotation from Kolmar's poem "The Jewess" 6 in which she expressed the hope that she would overcome her estrangement in the world by being "harnessed with turrets". These "turrets" could be interpreted as being the faith in the eternal tenets of the Jewish faith which would act as bastions of strength and give her protection against persecution. By placing a question mark behind the last verse, Bobrowski perhaps wished to emphasise the stark fact that in the face of the forces of darkness, faith is fragile and the "turrets" could not avert her death in the concentration camp.

The moving poem to the famous German-Jewish poet Else LaskerSchüler is even more explicit in its portrayal of Jewish suffering.

\title{
Else Lasker-Schüler
}

\author{
Windbruch \\ über die Erde \\ streu ich. Schwester. Jedes \\ ungestorbene Land \\ ist dein Grab. \\ Przemysl, Brzozow, wer \\ seine Stätte \\ aushob, ist \\ verscharrt. In Mielce das Haus \\ Gottes \\ brennend, über die Flammen \\ hinauf die Stimme, eine \\ Stimme, aber \\ aus hundert Mündern, aus \\ der Erstickung. Wie sagt \\ man: im Feuerofen \\ erhob sich das Lob \\ Gottes - wie sagt \\ man? \\ Ich weiß \\ nicht mehr. \\ Über die Erde, Schwester, \\ Windbruch, ausgestreut. Wie
}

6 See Bobrowski's own footnote to the poem (Bobrowski, 1987, 1:288). 
Bäume verkrallt

Gesehenes in

den Schatten mittags, in

die Dämmerung unter den Schwingen

der Vögel, in

das Eis, in

die Ödnis

nachts.

Liebe

(du sprichst aus dem Grab)

Liebe tritt, eine weiße

Gestalt,

aus der Mitte des Grauens.

Else Lasker-Schüler

Windfall

over the earth

I cast. Sister. Each

land, unperished,

is your grave.

Przemysl, Brzozow, he who

dug out

his grave, lies

buried. In Mielce the house

of God

burning, above the flames

rising, the voice, one

voice, yet

from a hundred mouths,

in suffocation. How does one

say: in the furnace of fire

the praise of God

was ascending - how does one

say?

I despair

in knowing.

Over the earth, Sister,

windfall, dispersed. Like

trees those images

clawed into

the shadows of noon, in

the twilight under the wings

of birds, in 
the ice, into

desolation

at night.

Love

(you speak from the grave)

Love advances, a figure

in white,

from the vortex of horrors.

(Bobrowski, 1987, 1:117-118.)

The lyrical voice of the poem casts an intangible force, identified as Windbruch, over the earth. I have tried to translate Bobrowski's abstract coinage with windfall but the expression does not convey the connotation of violent havoc and destruction inherent in the word, especially in the term Bruch (break). In metaphoric language the message is conveyed that the whole world is unhinged and becomes witness to the devastation caused by the Holocaust. This havoc becomes evident in the second stanza when the poet evokes the names of Polish towns which have "practically nothing to do with the poetess, who was born and raised in Berlin, and went to Palestine at the beginning of the Hitler regime" (Ireland, 1980:425). Bobrowski does not want to relate stations of her life, he wants to evoke scenes of suffering as experienced by so many Jews: the mass graves they often had to dig themselves, the gas chambers. At the same time he grapples with the problem of how to adequately express or portray the horror of the Holocaust.

It seems unlikely that Bobrowski, as serving member of the German invasion army of Poland and later in Russia was ever in Mielce or in the other two towns mentioned. Perhaps he became aware of the incidents portrayed in the poem through reports in the press or from fellow soldiers. As in the poem "Gertrud Kolmar", Bobrowski evokes the reaction to the horrors of the Holocaust with images from nature (trees, birds, night) and he shows its ominous effects on the landscape: shadows at noon, ice, darkness and desolation is descending over the world. Yet, paradoxically, the poet maintains that the praise of God still rises out of the furnace of the Holocaust. It is the great voice of suffering "in suffocation". In the last two stanzas, the poet alludes to the third chapter of the book of Daniel, where we are told that Daniel and his three friends were left unharmed in the blazing furnace protected by a "figure in white" looking "like an angel". Bobrowski is here invoking the promises of help and consolation that is in store for the people of God. There is hope that 
the language of love, even though it might be speaking "from the grave", will transcend the language of "the vortex of horrors".

Pictures or photographs were often Bobrowski's inspiration for a poem. One of the starkest poems he wrote is "Bericht" (Report). It is based on a photograph and the accompanying text in a book on the persecution of the Jews by Gerhard Schoenberner (1960:98), entitled Der gelbe Stern - die Judenverfolgung in Europa 1933-1945. The photograph depicts the interrogation of a Jewish girl by three German officers. According to the accompanying text the girl had "escaped from a death-transport out of the Warsaw Ghetto and then joined the Partisans". She was then arrested again by the Germans. The poem reads like a factual report of the interrogation following the caption of the photograph very closely: 7

\section{Bericht}

Bajla Gelblung,

entflohen in Warschau

einem Transport aus dem Ghetto,

das Mädchen

ist gegangen durch Wälder,

bewaffnet, die Partisanin

wurde ergriffen

in Brest-Litovsk,

trug einen Militärmantel (polnisch)

wurde verhört von deutschen

Offizieren, es gibt

ein Foto, die Offiziere sind junge

Leute, tadellos uniformiert,

mit tadellosen Gesichtern,

ihre Haltung

ist einwandfrei.

\section{Report}

Bajla Gelblung,

escaped in Warsaw

from a transport out of the Ghetto,

this girl

has walked through forests,

7 The photograph is reproduced in Selbstzeugnisse (Bobrowski, 1975:80). 
armed, a partisan,

apprehended

in Brest-Litovsk,

wearing a military coat (Polish)

interrogated by German

officers, there is

a photo, the officers are young

people, in impeccable uniforms,

with impeccable faces,

their deportment

is irreproachable.

(Bobrowski, 1987, 1:133.)

Bobrowski wants his readers to ponder over the last five lines of the poem and to reflect whether the manner of the interrogating officers in their "impeccable" uniforms, with their "impeccable faces" is really "einwandfrei", i.e. without reproach, because we know that the girl is doomed to die. As Ireland (1980:427) puts it, the soldiers "who have captured her will later insist that they were only being good soldiers".

\section{The trail of blood: reality of guilt}

Bobrowski does not want to "use poetic language to prosecute guilt, but rather to establish its reality" (Barnouw, 1973:35). The Jewish theme in his poems, his endeavour to look for the "trail of blood", is but a subtheme of a greater concern, namely the problematic history of the difficult and guilt-ridden relations of the German and East European peoples: the Poles, the Lithuanians, the Russians and "amongst them all the Jews" (Bobrowski, 1987, 4:335). This is a longer history than merely the Second World War, but can be traced back to the period of the colonisation of Eastern Prussia by the Teutonic knights. Bobrowski stated repeatedly that he considered this difficult relationship his own "Thema" and himself uniquely authorised to write about it in an authentic way "because I grew up in the vicinity of the river Memel" (Bobrowski, 1987, 4:335) in Eastern Prussia, and because he could trace the roots of his family right back to his Polish ancestry. In the formative years of his childhood before the Second World War he often spent holidays on the farm of his grandparents near Tilsit on the Lithuanian side of the river Memel. There he gained first hand experiences of the problems associated with the co-existence of German and East European people. It was a mode of life in which the Germans were almost always dominant and domineering, seeking to establish mastery over subservient people. And when the Second World War broke 
out, when Poland was occupied and "Operation Barbarossa" brought about the German invasion of Russia, Bobrowski was a soldier in the German army which was responsible for the destruction of centuries-old towns such as the Russian city of Nowgorod. He became a witness to the atrocities committed by the SS when Jews were being rounded up and brought into the concentration camps.

The shock of these experiences reverberate through the verse of his poetry once he found the maturity and the courage to deal with the subject of German Verschuldung as he personally perceived it. Bobrowski's use of the term, Verschuldung, rather than Schuld goes beyond simple guilt or culpability, but connotes the accumulation of guilt over many generations - including, but not limited to his own guilt through his involvement in the war of aggression in the East. He was to articulate this guilt in his own unique style using the images of nature of the "Sarmatian", i.e. Eastern landscape, creating a complex often enigmatic sign language to express his "Thema". One of the most poignant and significant poems in this regard is "Kaunas 1941":

\author{
Stadt, \\ Über dem Strom ein Gezweig, \\ kupferfarben, wie \\ Festgerät. Aus der Tiefe die Ufer \\ rufen. Das hüftkranke Mädchen \\ trat vor die Dämmerung damals \\ sein Rock aus dunkelstem Rot. \\ Und ich erkenne die Stufen \\ den Hang, dieses Haus. Da ist kein \\ Feuer. Unter dem Dach \\ lebt die Jüdin, lebt in der Juden Verstummen, \\ flüsternd, ein weißes Wasser \\ der Töchter Gesicht. Am Tor \\ lärmen die Mörder vorüber. Weich \\ gehn wir, im Moderduft, \\ in der Wölfe Spur. \\ Abends sahn wir hinaus \\ auf ein steinernes Tal. Der Habicht schwebte \\ um die breite Kuppel. \\ Sahen die Stadt, alt, \\ Häusergewirr hinunter \\ bis an den Strom
}


Wirst du über den Hügel gehn? Die grauen Züge

- Greise und manchmal die Knaben sterben dort. Sie gehn über den Hang, vor den jachernden Wölfen her.

Sah ich dich nicht mehr an, Bruder? An blutiger Wand schlug uns Schlaf. So sind wir weitergegangen, um alles blind. Im Eichwald drau $\beta$ en mit der Zigeuner Blick die Dörfer, hinauf um die Firste des Sommers Schnee.

Tief im Regengesträuch werd ich treten den Uferstein lauschen im Dunst der Ebenen. Da waren die Schwalben

stromhinauf und die Nacht grün, die Waldtaube rief: Mein Dunkel ist schon gekommen.

Town, branching across the river, copper-toned, like festive silver. From the depths the riverbanks call. The hip-crippled girl stepped out in the dusk, then, her skirt a dark-blazing red.

And I recognise the steps, the slope, this house. There is no fire. Under the roof lives the Jewess, lives in the muteness of Jews, whispering, a white water is the face of the daughters. At the gate the murderers' din of voices passes. Softly we tread, in the mouldering smell, in the tracks of the wolves.

At dusk we looked outside on to a stony valley. The hawk was circling the dome shaped steeple.

We saw the town, old, a maze of houses, stretching right down to the stream. 
Will you go over the

hillside? The grey processions

- old men and sometimes the youngsters -

die there. They go

over the slope, ahead of the

yapping pack of wolves.

Did I no longer see you,

brother? Against a bloodstained wall

sleep struck us down. Thus we

went on, to all things

blind. Outside in the oak-wood

villages, leering like

gypsies, right up to the roof tops

the summer's snow.

Deep in the rain thicket

I shall tread the stones on the river's bank,

listening in the haze of the plains. Then

the swallows

were upstream and the night was

green, the forest dove called:

My darkness has come already.

(Bobrowski, 1987, 1:60-61.)

This remarkable hermetic poem gains a layer of meaning if we read it in the light of Bobrowski's biography. The poet visited the Lithuanian town Kovno (Kaunas) with its large Jewish population twice before the war when he was thirteen years old. The brother of his mother was the editor of a German newspaper there (Gajek \& Haufe, 1977:8). He saw this childhood territory again during the war as member of a communications unit belonging to the invading Third German army of the "Heeresgruppe Nord". He himself remarked later that the traumatic experiences of the war were like an injury which marked him for the rest of his life.

Bobrowski's poem begins with a description of the town on the banks of the river. The calling "from the depths" evokes the De profundis of Psalm 130 and foreshadows the deep emotional concern and deep personal despair of the poet. The "town above the river" and the hip-crippled girl with the blazing red skirt in the sunset bring back memories of the war of 1941 when Bobrowski witnessed how Jews went into hiding in the town because the "wolves", Bobrowski's symbol for the SS, were rounding up and killing them. The Jewish woman is hiding with her daughters, their ghostly white faces already marked by imminent death. 
Only fairly recently the Bobrowski scholar, Haufe, has revealed the following biographical information that has a direct bearing on the poem:

On 28th June 1941, during the invasion into the Soviet Union, the soldier [Bobrowski] witnessed a pogrom that was initiated by the Security Police and in which 3800 Jews lost their lives; hundreds of them were clubbed to death with iron rods by prison inmates who had been set free. This was seen by Bobrowski walking in the 'tracks of the wolves', this is the background to the poem 'Kaunas 1941'. (Tgahrt, 1993:467; translation - FW.)

But the poem goes further than detailing the horrible events of the pogrom. It undergoes a change of tone when instead of the collective pronouns ("we" and "us"), the "I" is introduced: "Did I no longer see you / brother?"

The poet thus examines his own involvement in the events of those days. The first part of the fifth stanza can therefore be understood as a dialogue with his own conscience. He asks the cardinal question why he did not see the "brother" in the persecuted Jew, when "the bloodstained wall", a metaphor for the killings, was a visible sign of the crimes against the Jews. He asks why he was struck down by "sleep", a condition in which he could escape culpability, why he with his fellow Germans (the "I" reverts to the "we") went on in blindness and did not take notice of the "grey processions" as Jews were led "over the hill" to the place of execution: "old men and sometimes the youngsters die there".

It may be asked what the significance is of this remarkable "confession" of "blindness to the fate of the Jews". It is necessary to digress briefly and relate some salient events in Bobrowski's biography before returning to this poem. The publication of Bobrowski's collected works in 1987 by Eberhard Haufe brought the surprising revelation that among his previously unpublished poems (before, during and after the war up to 1954) there was not a single text which revealed a concern with the fate of the Jews. His earliest published odes of 1941-1943 speak eloquently of the war-ravaged Russian landscape and the devastated Russian towns (Nowgorod). Yet they do not pose the obvious question about who was to blame for this destruction. The ruthless campaigns of the SS are not 
mentioned. It is as if Bobrowski (like so many Germans) was oblivious to the suffering of the Jews. 8

Bobrowski came from a committed Christian family. He was a member of the Confessing Church of Prussia which protested against the Nürnberg Laws of September 1935 when Jews were made outcasts in the state of Germany. The synod of this Confessing Church subsequently issued a courageous statement on the situation of nonArians in which it spoke of the shame and guilt resting on German Christians who tolerated the persecution of Jews and even tried to justify this "evil" as the will of God (Gajek \& Haufe, 1977:547 ff.). Yet Bobrowski does not even mention the Jews in his works before 1956.

When he returned to his family in East Berlin after the war in 1949, he had spent four years in Russian labour camps. He professed to have become a Communist. However, he soon rediscovered the basic tenets of his Christian faith. The turning point in his life came in 1956 when, after a period of critical self-examination that probably began in 1952, he suddenly must have realised that he himself was tainted by the crimes committed by Germans against Jews. To use the language of "Kaunas 1941", his formerly "blind" eyes were opened, and he woke up from his long "sleep". The circumstances around this "conversion" have never really been explained satisfactorily. Perhaps the intensive reading of the writings of his favourite worldly "saint", the 18th century writer, theologian and philosopher Johann Georg Hamann from Königsberg (and great antipode of Kant), whose complete works he bought in March 1956 and subsequently studied intensively, influenced this process. Hamann was a highly original thinker of the Enlightenment but after his "Con-

8 The former German President, Richard von Weizsäcker, himself a former soldier in the Wehrmacht, acknowledged this "blindness" and stressed the culpability of the German people for the crimes committed against the Jews in his address to the German nation on the 40th anniversary of the end of the war in May 1985 when he said:

\footnotetext{
Every German was in a position to realise what the Jewish citizens had to suffer ... Who could remain unsuspecting after the fire in the synagogues, the looting, the stigmatisation with the Star of David, the revocation of rights, the constant violations of human dignity? Anyone who opened his eyes and ears could not have failed to notice that the deportation trains were on the move ... there were also attempts by all too many people not to take notice of what was happening, also by people of my generation who were young at the time and not involved in the planning and realisation of these acts. (Von Weizsäcker, 1985:13.)
} 
version" in London he tried to put his faith into practice without abdicating the powers of reason. He recorded in his autobiographical "Gedanken über meinen Lebenslauf" ("Thoughts on my life") how his profound spiritual experience in London in 1758 was prompted by a meditation on the story of Cain's fratricide. Hamann (quoted in Seils, 1987:60) writes:

I realised my own crime in the history of the Jewish people, I read the story of my own life ... I thought of Abel, about whom God said: the earth has opened its mouth in order to receive the blood of your brother. I felt my heart beating, I heard a voice in the depth of my heart sighing and wailing, being the voice of the slain brother, who wanted to avenge his blood if I would not listen in time and continued to shut my ear against it ... Suddenly I felt my heart welling up, it poured forth with tears and I could no longer conceal before God that I was the murderer of the brother, the murderer of his only begotten son. (Translation - FW.)

It is plausible that the significance of this passage struck Bobrowski forcibly and induced him to reflect on his own experiences during the war and his own blindness towards the plight of the Jews.9 Bobrowski's letter of October 1956 to his friend Hans Ricke seems to bear out this new-found moral impetus because in it he revealed for the first time that he was planning to write a book of poems with which he could do penance for his historical blindness and contribute to reconciliation. Bobrowski (1987, 1:43 ff.) wrote:

I do not only want to make nice poems ... I want to do something with my verse ... and this is of existential importance to me. I want to write my poems with my whole muddled life, with my shortcomings and failures, spiritually and physically ... I want to do something for which I think I have achieved the necessary aptitude namely through my heritage and my ancestry, through my education and my experiences ...

Therefore the events of the last war, the war of the Nazis, will be for me a cardinal and perhaps the most important part (in the book of poetry about the eastern nationalities, their history, customs, myths etc. and the aggressive role the German people played in the East). Thus I shall stand in these poems, in uniform and highly conspicuous ... This must be my

9 Bobrowski in a letter to his friend Peter Jokostra in 1959 quoted Hamann when he wrote: "Each Jew is for me an incomprehensible miracle; I cannot live without it." 
contribution to the expiation of a vast historical guilt of my people not to be overlooked, perpetrated against those Eastern nationalities. (Translation - FW.)

In the same month (October 1956), Bobrowski wrote a poem which likewise can be interpreted as a "confessio". Though the "l" in the text "Lettische Lieder" (Latvian songs) is masked by the role of a Latvian peasant, there can be no doubt that Bobrowski refers to himself. This poem (Bobrowski, 1987, 1:57) is a text of great poignancy because of the accusations that the "I" levels against itself. The lyrical subject recognises the streak of the "murderer" in himself and in his ancestry and not only in the figure of Lord Uexküell, a German nobleman in the seventeenth century who, as Bobrowski explains in his notes to the poem, stood accused by the Riga town councillors of murdering one of his Latvian servants.

\section{Lettische Lieder}

Mein Vater der Habicht.

Großvater der Wolf.

Und der Ältervater der

räubrische Fisch im Meer

Ich, unbärtig, ein Narr,

an den Zäunen taumelnd,

mit schwarzen Händen

würgend ein Lamm um das Frühlicht. Ich,

der die Tiere schlug

statt des weißen

Herrn, ich folg auf zerspülten

Wegen dem Rasselzug,

durch der Zigeunerweiber

Blicke geh ich. Dann

am baltischen Ufer

treff ich den Uexküell, den Herrn

Er geht unter dem Mond.

Ihm redet die Finsternis nach.

\section{Latvian songs}

My father the hawk.

Grandfather the wolf.

And my ancestor the

predator fish in the sea. 
I, beardless, a fool, staggering along the fences, with black hands strangling a lamb at dawn. I,

who slew the animals instead of the white Lord, I follow on eroded paths the procession of rattles

through the glances of gipsy women I pass. Then on the Baltic coastline I meet Uexküell, the lord.

He's walking under the moon.

Voices of darkness are trailing him.

The inter-textual relationship between "Latvian songs" and "Kaunas 1941" which was written a few months later (1957) makes it possible to trace the trail of guilt and blood which the poet pursues in his Jewish poems. Remembering the crimes perpetrated against the Jews means for Bobrowski not only to remember the "blindness" to the suffering of the "brother" but also to be conscious of his own "black hands", his blundering along the "fences" of indecision, and his own association through ties of blood and language with the "wolves", the "hawks", the predators. The repetition of the "l" at the beginning and the end of the second stanza should be noted since it stresses the mea culpa. This feeling of guilt also explains the overshadowing tone of sadness pervading Bobrowski's poems on the Jewish theme.

Returning briefly once more to the poem "Kaunas 1941" we should note its sombre ending. Although the "l" proceeds in blindness, the villages with their furtive glances like gypsies express fear and the oxymoron "summer's snow" is a powerful expression of the advent of the cold front of terror which the coming of the "wolves" heralded. The last stanza is about the aftermath of the frightening events in Kaunas. The lyrical subject, we are told, is in the midst of the "rain thicket" on the riverbank, rain being in Bobrowski's metaphorical language a sign for an impending judgement which comes akin to a flood. The haze of the brooding Sarmatian plain is like an overpowering white noise, creating an impression of impending doom. Swallows, a metaphor for innocent life and homecoming, have flown away and the call of the forest dove reiterates that darkness (with its connotations of guilt) has settled over this landscape. 


\section{5. "Knock off the rust from the walls and the steps": the promise of a new life}

In his dialogue with his reader on the theme of Jewish suffering, Bobrowski does not leave matters "in the depths of despair" but he is looking for words of consolation and for signs of new life in the aftermath of the Holocaust. This becomes apparent in his texts on the Jewish poets Gertrud Kolmar and Else Lasker-Schüler, but can also be demonstrated by a brief discussion of the text "Wiedererweckung" (Resuscitation), a poem that wants to show that a life of new beginning and new hope is possible after the Holocaust. Bobrowski wrote it in the same dark winter month as his narrative prose passage discussed in the introduction.

"Wiedererweckung" is dedicated to the Jewish poet Paul Celan with whom Bobrowski corresponded and whom he admired, although he could ultimately not identify with his poetry. Bobrowski believed in the revelatory and redemptive power of poetic language whereas Celan's poems are characterised by a growing scepticism about the efficacy of words. His later poetry shows a decided tendency towards "Verstummen" (becoming mute). Bobrowski's poem with the programmatic title "Wiedererweckung" (Resuscitation), which can also be translated as "Reawakening" or "Resurrection", can be read as a direct contradiction of Celan's statement in his poem "Nächtlich geschürzt", where he had declared that words were lifeless corpses (“Ein Wort - du weißt: / eine Leiche ...").10 The text of Bobrowski's poem reads as follows:

\section{Wiedererweckung}

Das

Land

leer,

durch ausgebreitete Tücher

heraufgrünt das andre, darunter-

gelegte, das ein Verdacht

war

früher. Es kommt

aus der Pestzeit, wei $\beta$

von Knochen, Rippen, Wirbeln,

Speichen, vom Kalk.

10 For a detailed interpretation of "Wiedererweckung" and the controversy between Bobrowski and Celan, cf. Deskau (1974:46 ff.) and Reichert (1989:37-53). 


\section{Zähl \\ die Gräser \\ und zähl}

Fäden aus Regenwasser, und Licht, die Blättchen

zähl, und zeichne ein

deine Schritte, Wildspuren, und Stimmen, beleb

mit Worten

das Blut in den Bäumen und

den Lungen, den Rost

schlag von Wänden

und Stufen,

an deinen Händen

bleibt er, dort mag er sich

nähren

mit deinen Nägeln.

Es ist nicht die Zeit, ihn zu fragen.

Es ist die Zeit für das Wasser

an Halmen, für die erneute

Fügung der Blätter, und Augen

öffne das Laub.

\section{Resuscitation}

The

land

desolate,

through outspread sheets,

green, sprouts the other, under-

neath, this layer

was

only an inkling long ago. It dates

from the time of the plague, white

with bones, ribs, vertebrae,

spines, calcareous.

\section{Count}

the grass blades

and count

ribbons of rainwater

and light, the small leaves

count, and imprint

your steps, animal tracks,

and voices, quicken

with words

the blood in the trees and 
the lungs, knock off

the rust from the walls

and the steps,

on your hands

its stains remaining, where it may be

nourished

with your nails.

It is not the time for recriminations.

It is time for the water

on rushes, for the renewed

formation of leaves, and foliage

open-eyed.

(Bobrowski, 1987, 1:205.)

The first stanza portrays a landscape devastated by the plague with the relics of devastation to be seen in the field of bones and other calcareous remains. The poem alludes to the text of the prophet Ezekiel, chapter 37 where he has a vision of a valley littered with dry bones. At the same time the passage evokes historical periods of "black death" in Europe often linked to violent persecution of Jews. And of course the most recent "Pestzeit", the Holocaust, must be understood in this context. At the same time the first stanza draws attention to another layer of "green sprouts" underneath that penetrates the desolate sheets of bones.

The second stanza shows the remarkable reawakening of new life in so many phases that the "valley of bones" becomes transformed into a valley of life. The lyrical subject is commanded to observe all the new signs of life and to remove the "rust" (the visible deposit of human guilt and human crimes) so that a new beginning is possible. These remnants of the "trail of blood" must be knocked off from the walls and the steps. Penance must be done, Wiedergutmachung! Yet human guilt can never be undone entirely, since the "rust" remains as a stain on the hands and nails and stays as a reminder of the horrors of the past.

The third stanza is aglow with an eschatological hope that a new life of growth is possible, for the Jews, indeed also for the Germans. Poignant images of nature proliferate: life-giving water on rushes, and the growth of new foliage "open-eyed" point to this act of recreation. The sombre vision of the valley of bones linked to the fate of the Jews in the Holocaust is not the ultimate vision - it was a reality and should always be remembered - but the poem closes with a new vision of the new creation as a configuration of hope and a prefiguration of the "Zeit ohne Angst" (the "time without fear"). 
From one of Bobrowski's early unpublished poems the following verses can be quoted in conclusion to sum up his hope for the future:

... ruf ich zu euch

Gequälte. Kommt, Juden, slavische Völker, kommt,

...

da $\beta$ ich an eures Lebens

Stromland der Liebe vertane

Worte lernte, die Reiser,

die wir pflanzen den Kindern

würden ein Garten.

Im Licht.

... I call all of you

tortured people. Come Jews,

Slavic people, come

...

that on your lives'

flood plain I might learn anew

long wasted words of love, the saplings

that we plant for the children

would then be a garden.

Of light.

\section{List of references}

BARNOUW, D. 1973. Poetry of co-existence: Johannes Bobrowski on "The German East". Mosaic, 6(4):21-38.

BOBROWSKI, J. 1975. Selbstzeugnisse und neue Beiträge über sein Werk. Berlin: Union.

BOBROWSKI, J. 1987. Gesammelte Werke. T. 1-4. Ed. by E. Haufe. Berlin: Union.

DESKAU, D.1975. Der aufgelöste Widerspruch: "Engagement" und "Dunkelheit" in der Lyrik Johannes Bobrowskis. Stuttgart: Klett.

GAJEK, B. \& HAUFE, E. 1977. Johannes Bobrowski: Chronik-EinführungBibliographie. Frankfurt: Peter Lang.

IRELAND, L. 1980. "Your hope is on my shoulder": Bobrowski and the world of the Ostjuden. Monatshefte, 72(4):416-430.

RAABE, W. 1963. Gesammelte Werke. T. 1. Ed. by K. Hoppe. Berlin: Klemm.

REICHERT, S. 1989. Das verschneite Wort: Untersuchungen zur Lyrik Johannes Bobrowskis. Bonn: Bouvier.

SCHOENBERNER, G., Red. 1960. Der gelbe Stern: die Judenverfolgung in Europa 1933 bis 1945. Gütersloh: Bertelsmann.

SEILS, M., Red. 1987. Johann Georg Hamann: eine Auswahl aus seinen Schriften: Entkleidung und Verklärung. Wuppertal: Brockhaus.

TGAHRT, R., Red. 1993. Johannes Bobrowski oder Landschaft mit Leuten. Marbacher Kataloge 46. Marbach: Deutsche Schillergesellschaft. 
VON WEIZSÄCKER, R. 1985. Rede zum 40: Jahrestag des Kriegsendes. Deutschland, 2:13 1994. (Eng. ed.)

\section{Key concepts:}

Bobrowski, Johannes

East German literature Eastern Europe

Holocaust

Jews

memory

\section{Kernbegrippe:}

Bobrowski, Johannes

herinnering

Holocaust

Jode

Oos-Duitse literatuur

Oos-Europa 